\title{
Thrombocytopenia as First Manifestation of Acute Massive Pulmonary Embolism
}

\author{
Akut Masif Pulmoner Embolinin ilk Belirtisi Olarak Trombositopeni
}

Nai-Chien Huan, Kang Yang Ng, Khai Lip Ng, Jamalul Azizi Abdul Rahaman

\section{Abstract}

Massive acute pulmonary embolism (PE) is a lifethreatening medical condition. Occasionally, patients experiencing a massive PE may develop concurrent thrombocytopenia. A 64-year-old female was admitted for left femur osteomyelitis with a sub-periosteal abscess that was causing pain and immobility. There were no indications suggesting underlying thrombophilia or malignancy. On day 5 of admission, the patient developed acute onset respiratory distress, necessitating intubation and vasopressor support. A computed tomography pulmonary angiogram revealed a massive PE involving the left main trunk and left ascending pulmonary artery. The patient had experienced an unexplained worsening thrombocytopenia that despite without heparin use previously. There was clear indication for thrombolysis, but the treatment was contraindicated. After a multidisciplinary meeting it was decided to optimize platelet counts prior to the performance of a surgical embolectomy, however the patient succumbed 2 days later. The unexplained thrombocytopenia could be the only clue for massive PE. Clinicians should remain vigilant to ensure early diagnosis and improved outcomes.

Key words: Pulmonary embolism, thrombocytopenia, thrombosis.

\section{Özet}

Masif pulmoner emboli (PE) hayatı tehdit eden medikal bir durumdur. Bazen, masif PE geçiren hastalarda, eşlik eden bir trombositopeni görülebilir. Sol femurda ağrı ve hareket kısıtlığına neden olan subperiostal apseli osteomiyeliti bulunan 64 yaşındaki kadın hasta yatırıldı. Altta yatan trombofili veya maligniteyi düşündüren bir bulgusu yoktu. Yatışın beşinci gününde, vasopresör desteği ve entübasyon gerektiren akut bir solunum sıkıntısı ortaya çıktı. Pulmoner tomografik angiografide, sol inen pulmoner arter ve sol ana pulmoner arterde masif bir pulmoner emboli görüldü. Öncesinde heparin kullanmamasına rağmen açıklanamayan trombositopeni gelişti. Trombolitik tedavi ihtiyacı olmasına rağmen, bu tedavi kontrendike idi. Multidisipliner bir toplantıda cerrahi embolektomi öncesi trombosit sayısını düzeltme kararı alındı. Ancak hasta iki gün içinde kaybedildi. Açıklanamayan bir trombositopeni masif PE için tek ipucu olabilir. Klinisyenlerin, erken tanı ve daha iyi sonuçlar elde etmeleri için dikkatli olmaları gerekir.

Anahtar Sözcükler: Pulmoner emboli, trombositopeni, trombozis.

Submitted (Başvuru tarihi): 09.09.2020 Accepted (Kabul tarihi): 14.11.2020

Correspondence (iletişim): Nai-Chien Huan, Department of Pulmonology, Serdang Hospital, Kajang, Malaysia

e-mail: naichien_1@yahoo.com 
Venous thromboembolic diseases (VTE) such as deep vein thrombosis (DVT) and pulmonary embolism (PE) are commonly encountered in daily clinical practice. Massive acute $\mathrm{PE}$, defined as systolic arterial pressure of less than $90 \mathrm{mmHg}$, is a life-threatening medical condition $(1,2)$. Occasionally, patients with massive PE can present with concurrent thrombocytopenia of various etiologies, including heparin-induced thrombocytopenia (HIT) and acute thrombosis associated thrombocytopenia, leading to diagnostic and therapeutic dilemmas $(3,4)$. In this case report, we present a patient with massive PE with thrombocytopenia, as first manifestation of the disease without prior heparin use.

\section{CASE}

A 64-year-old female with no prior medical conditions was admitted to an orthopedic unit complaining of worsening pain and swelling in the left thigh, leading to physical immobility for approximately one month prior to admission. She reported no preceding falls or physical trauma, although she had attended multiple left thigh acupuncture sessions with an unlicensed practitioner in an attempt to relieve the pain in the left thigh. There were no other signs or symptoms suggesting underlying thrombophilia, malignancy or connective tissue disease. A magnetic resonance imaging (MRI) of the left thigh revealed features of osteomyelitis in the distal one-third of the left femur with adjacent collection, consistent with a diagnosis of left femur osteomyelitis with a subperiosteal abscess (Figure 1). With this diagnosis in mind, the patient was scheduled for open drainage and a washout of the abscess. Her baseline blood values upon admission, the results of renal and liver function tests, and her coagulation profile were unremarkable. Her hemoglobin level was $12 \mathrm{~g} / \mathrm{dl}$, and her platelet count was $409 \times 10^{9} / \mathrm{L}$. She had leukocytosis at $17.4 \times 10^{9} / \mathrm{L}$ with a raised $\mathrm{C}$-reactive protein level of $302 \mathrm{mg} / \mathrm{L}$.

On day 5 of admission, while waiting for an operation, she developed acute onset respiratory distress, necessitating urgent intubation, mechanical ventilation and vasopressor support. Prior to this, she had experienced unexplained worsening thrombocytopenia for 4 days (from $409 \times 10^{9} / \mathrm{L}$ on admission to $22 \times 10^{9}$ on day 5 th of stay) without heparin use. Her hemoglobin and total white cell counts and coagulation profile remained stable (Figure 2) An urgent peripheral blood film revealed no evidence of acute hemolysis, abnormal platelet clumping or presence of blast cells to suggest an underlying hematological malignancy. Other blood parameters, including renal and liver function test results, were all within normal ranges. An urgent computed tomography pulmonary angiogram revealed massive PE involving the left main trunk and the left ascending branch of the pulmonary artery (Figure 3). There was a clear indication for thrombolysis, but the treatment was contraindicated. After a multidisciplinary consultation involving internal medicine physicians, nurses, orthopedic surgeons, intensive care doctors, cardiothoracic surgeons and cardiologists, it was decided to optimize the platelet counts prior to consideration for surgical embolectomy. Unfortunately, she succumbed after 2 days, despite maximal supportive therapy.

\section{DISCUSSION}

The basis of PE treatment is anticoagulation, with systemic thrombolysis being the treatment of choice in patients with massive PE (5). PE treatment, however, needs to take into consideration various factors, including, but not limited to, the severity of $\mathrm{PE}$, bleeding risk, and patient factors such as history of allergies to heparin or HIT. Our case report highlighted a clinical dilemma with strong indications for systemic thrombolysis and anticoagulation that unfortunately were accompanied by high bleeding risks due to concurrent severe thrombocytopenia.

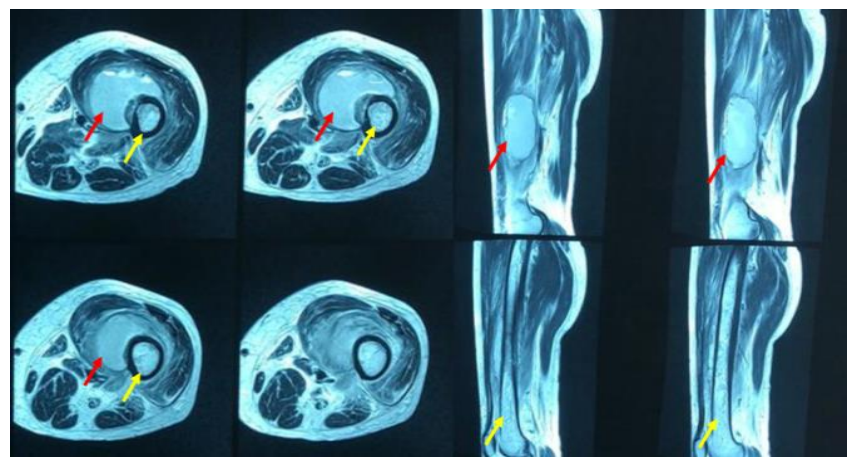

Figure 1: MRI images of left thigh demonstrating features of femur osteomyelitis with huge periosteal collection (red arrows). Femur marked with yellow arrows 


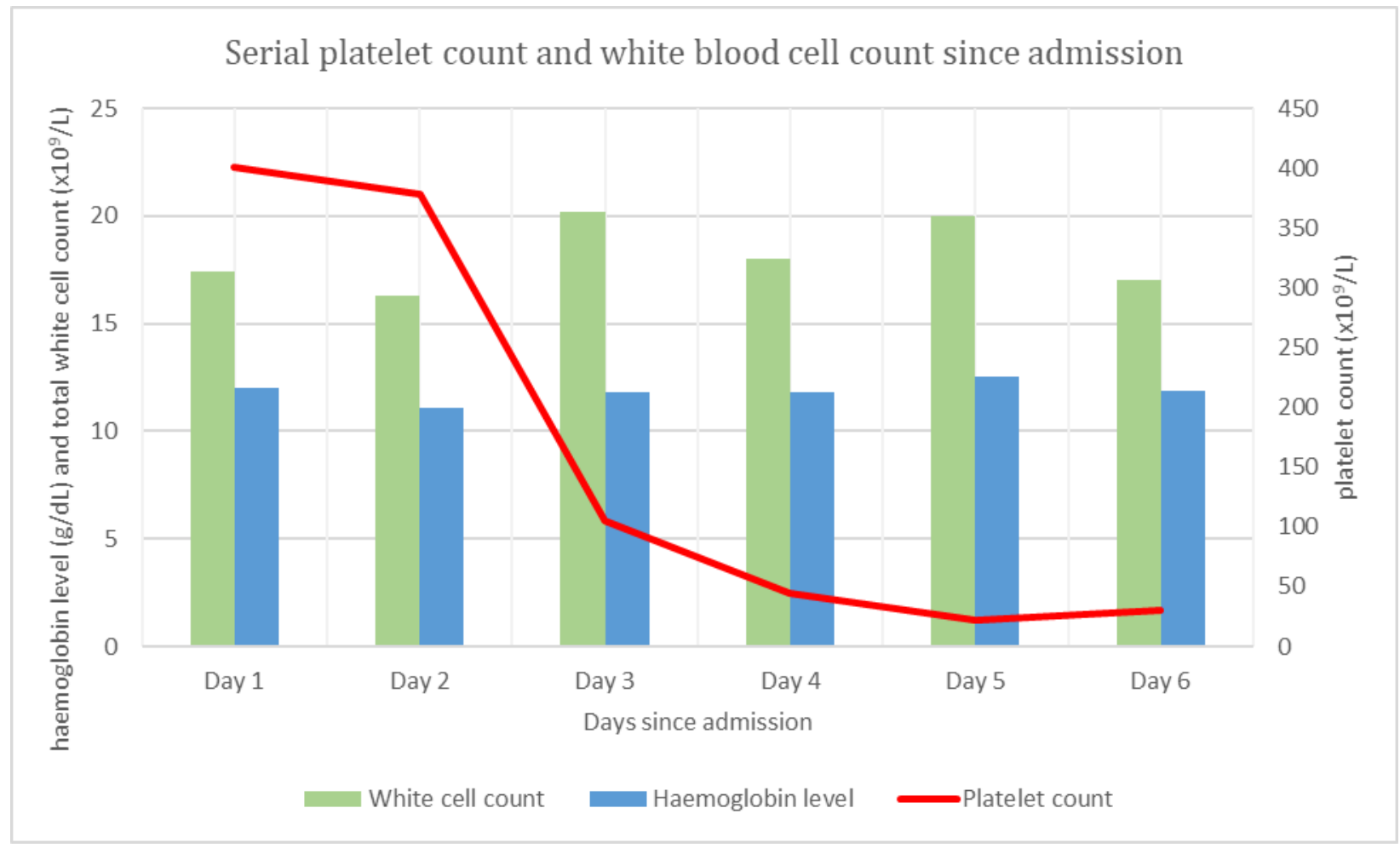

Figure 2: Serial platelet count, white blood cell count and haemoglobin levels since admission

Data on the role and safety of anticoagulation in patients with thrombocytopenia are scarce (6). Clinical workup and management should thus be tailored toward identifying and managing the potential causes of concurrent thrombocytopenia and thrombosis, such as HIT, disseminated intravascular coagulopathy (DIC), paroxysmal nocturnal hemoglobinuria (PNH), anti-phospholipid antibody syndrome, sepsis and hematological malignancies, as well as systemic malignancies with marrow infiltration and thrombotic tendencies $(3,6)$. Our patient received no forms of heparin prophylaxis prior to orthopedic surgery throughout admission, rendering a diagnosis of HIT unlikely, consistent with Warkentin's exclusionary criteria for HIT (7). Furthermore, there were no clinical signs or symptoms to suggest concurrent thrombophilia, malignancy or connective tissue conditions. Furthermore, laboratory results were not suggestive of conditions such as $\mathrm{PNH}$, DIC, hematological malignancies or connective tissue conditions. Her baseline platelet counts and coagulation profile were normal upon admission.

Thrombocytopenia in sepsis can occur due to various mechanisms. In patients with sepsis, activated platelets bind to the endothelium, leading to platelet sequestration and destruction $(8,9)$. Immune mediated mechanisms and the cytokine-driven hemophagocytosis of platelets can all contribute to low platelet counts in a patient with sepsis $(10,11)$. Patients with severe sepsis are often in a net procoagulant state with a secondary consumption of platelets, such as those observed in cases of DIC (12). While we acknowledge that sepsis may have contributed to thrombocytopenia in our case, it is unlikely to be the main driving or causative factor, for two reasons. Firstly, prior to development of sudden onset respiratory distress, the patient was stable and demonstrate no other clinical signs or symptoms of severe sepsis, such as bleeding, shock or organ dysfunction. Furthermore, her blood parameters, including coagulation profile, liver function tests and renal function, were all normal throughout admission, despite the concurrent worsening thrombocytopenia.

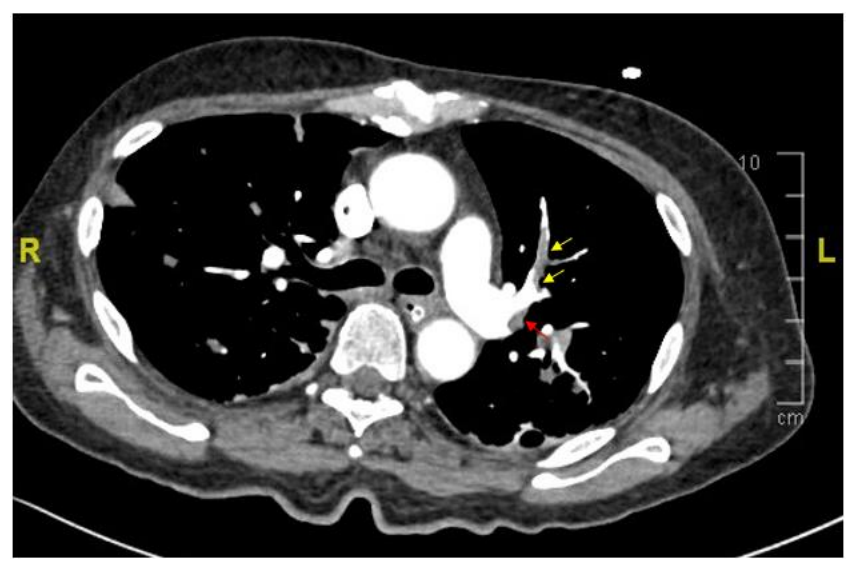

Figure 3: : Computed tomography pulmonary angiography demonstrating filling defects along left main pulmonary artery trunk (red arrow) and left ascending pulmonary artery (yellow arrows) due to pulmonary embolism 
As mentioned previously, there is only limited data on the use of thrombolysis in patients with thrombocytopenia. Alternative treatments including endovascular embolectomy and surgical embolectomy after the correction of platelet counts have been proposed and reported in various case reports, with mixed results $(3,13-16)$. Our patient was initially considered for a surgical embolectomy after the optimization of platelet counts, but she succumbed to her illness before we were able to carry out the procedure.

We postulated that large fresh clots in her pulmonary circulation had led to platelet adherence on the clot surfaces due to the exudation of thromboplastic substances. This phenomenon has been termed 'acute thrombosisassociated thrombocytopenia' (4). In 1887, Welch, a prominent founding professor of John Hopkins Hospital, demonstrated that platelets rapidly adhere to fresh thrombi, with the youngest thrombi attracting the largest number of platelets (17). This phenomenon is observed histologically as the Lines of Zahn, and is characteristic of thrombi formation with laminations formed by successive depositions of platelets and fibrinous materials seen as pale lines alternating with trapped red blood cells seen as dark lines (18). Subsequent studies, including the Urokinase Pulmonary Embolism Trial in 1971, showed that $10 \%$ of all patients with PE had platelet counts below 150 x109/L (19). A more recent study by Monreal et al. (20) revealed $P E$ to be associated with a significant reduction in platelet counts, a phenomenon not seen among patients with DVT without PE.

To our best knowledge, however, there have been no prior studies or reports specifically addressing thrombocytopenia as the first manifestation of acute massive PE. It remains unknown whether the rate of platelet decline is correlated with the severity of PE. Nevertheless, in light of our clinical encounter, we recommend that clinicians remain vigilant when dealing with patients with unexplained thrombocytopenia, and consider acute thrombosis associated thrombocytopenia in high risk patients. Earlier diagnosis during a 'safer' platelet count window may change the patient's clinical course and outcome by allowing more time for the consideration of medical and surgical therapy in the presence of massive PE.

\section{CONCLUSION}

We present here a patient with massive PE associated with severe thrombocytopenia necessitating systemic thrombolysis and anticoagulation, which unfortunately were contraindicated. Clinicians need to be vigilant when dealing with patients with unexplained thrombocytopenia, and to consider acute thrombosis associated thrombocytopenia, especially among high risk patients. Early detection and prompt intervention are vital to ensure a better clinical outcome.

\section{CONFLICTS OF INTEREST}

None declared.

\section{AUTHOR CONTRIBUTIONS}

Concept - N.C.H., K.Y.N., K.L.N., J.A.A.R.; Planning and Design - N.C.H., K.Y.N., K.L.N., J.A.A.R.; Supervision N.C.H., K.Y.N., K.L.N., J.A.A.R.; Funding -; Materials N.C.H., K.Y.N., K.L.N; Data Collection and/or Processing - N.C.H., K.Y.N., K.L.N; Analysis and/or Interpretation - N.C.H.; Literature Review - N.C.H., K.Y.N., K.L.N., J.A.A.R.; Writing - N.C.H.; Critical Review J.A.A.R.

\section{YAZAR KATKILARI}

Fikir - N.C.H., K.Y.N., K.L.N., J.A.A.R.; Tasarım ve Dizayn - N.C.H., K.Y.N., K.L.N., J.A.A.R.; Denetleme N.C.H., K.Y.N., K.L.N., J.A.A.R.; Kaynaklar -; Malzemeler - N.C.H., K.Y.N., K.L.N; Veri Toplama ve/veya İşleme N.C.H., K.Y.N., K.L.N; Analiz ve/veya Yorum - N.C.H.; Literatür Taraması - N.C.H., K.Y.N., K.L.N., J.A.A.R.; Yazıyı Yazan - N.C.H.; Eleştirel İnceleme - J.A.A.R.

\section{REFERENCES}

1. Torbicki A, van Beek EJR, Charbonnier B, Meyer G, Morpurgo $M$, Palla $A$, et al. Guidelines on diagnosis and management of acute pulmonary embolism. Task Force on Pulmonary Embolism - European Society of Cardiology. Eur Heart J 2000; 21:1301-36. [CrossRef]

2. Kasper W, Konstantinides S, Geibel A, Olschewski M, Heinrich F, Grosser KD, et al. Management strategies and determinants of outcome in acute major pulmonary embolism: results of a multicenter registry. J Am Coll Cardiol 1997; 30:1165-71. [CrossRef]

3. Munoz Tovar RA, Alvares Perdomo LC, Rojas Molina SM, Salazar SJ. Submassive pulmonary thromboembolism in a patient with thrombocytopenia: Therapeutic challenge. Case Rep Crit Care 2019; Article ID 1919401. [CrossRef

4. Kitchens CS. Thrombocytopenia due to acute venous thromboembolism and its role in expanding the differential diagnosis of heparin-induced thrombocytopenia. Am J Hematol 2004; 76: 69-73. [CrossRef] 
5. Aggarwal V, Nicolais CD, Lee A, Bashir R. Acute management of pulmonary embolism. American College of Cardiology. https://www.acc.org/. Oct 2017.

6. Lim MS, Enjeti AK. Safety of anticoagulation in the treatment of venous thromboembolism in patients with haematological malignancies and thrombocytopenia: Report of 5 cases and literature review. Crit Rev Oncol Hematol 2016; 105:92-9. [CrossRef]

7. Warkentin TE. Heparin-induced thrombocytopenia. In: Kitchens, CS, Alving BM, Kessler CM, eds. Consultative hemostasis and thrombosis. Philadelphia: W.B. Saunders; 2002: 355-372.

8. Mavrommatis AC, Theodoridis T, Orfanidou A, Roussos C, Christopoulou-Kokkinou V, Zakynthinos S. Coagulation system and platelets are fully activated in uncomplicated sepsis. Crit Care Med 2000; 28:451-7. [CrossRef]

9. Ghosh TK, Khan N, Malik A. Platelet auto-antibodies in septicaemic patients. Indian J Pathol Microbiol 1999; 42:31-5.

10. François B, Trimoreau F, Vignon P, Fixe P, Praloran V, Gastinne $\mathrm{H}$ : Thrombocytopenia in the sepsis syndrome: role of hemophagocytosis and macrophage colonystimulating factor. Am J Med 1997; 103:114-20. [CrossRef]

11. Stephan F, Thioliere B, Verdy E, Tulliez M. Role of hemophagocytic histiocytosis in the etiology of thrombocytopenia in patients with sepsis syndrome or septic shock. Clin Infect Dis 1997; 25:1 159-64. [CrossRef]

12. Venkata C, Kashyap R, Farmer JC, Afessa B. Thrombocytopenia in adult patients with sepsis: incidence, risk factors, and its association with clinical outcome. J Intensive Care 2013; 1: 9. [CrossRef]
13. Zalpour A, Hanzelka K, Patlan JT, Rozner MA, Yusuf SW. Saddle pulmonary embolism in a cancer patient with thrombocytopenia: a treatment dilemma. Cardiol Res Pract 2010;2011:835750. [CrossRef]

14. Badreldin HA, Rimsans J, Connors JM, Wiviott SD. Use of systemic bivalirudin with catheter-directed thrombolysis in a patient with heparin-induced thrombocytopenia: A case report. Catheter Cardiovasc Interv 2018; 91:E17-20. [CrossRef]

15. Bethea BT, Elliot JW, Richardson JB, Ahmed MI. Treatment of pulmonary embolism with argatroban and ultrasound-assisted catheter-directed thrombolysis with alteplase in a patient with heparin-induced thrombocytopenia. Am J Health-Syst Pharmy 2017; 74:1 153-7. [CrossRef]

16. laccarino A, Frati G, Schirone L, Saade W, lovine E, D'Abramo $M$, et al. Surgical embolectomy for acute massive pulmonary embolism: state of the art. J Thorac Dis 2018; 10:5154-61. [CrossRef]

17. Welch WH. The structure of white thrombi. Trans Pathol Soc Philadelphia 1887; 13:25-43.

18. Adelson E, Rheingold JJ, Parker O, Buenaventura A, Crosby WH. Platelet and fibrinogen survival in normal and abnormal states of coagulation. Blood 1961; 17:267-81. [CrossRef]

19. Urokinase pulmonary embolism trial. Circulation 1973; 47(Suppl II): 1 - 108.

20. Monreal M, Barba R, Tolosa C, Tiberio G, Todolí J, Samperiz AL. RIETE Investigators. Deep vein thrombosis and pulmonary embolism: the same disease? Pathophysiol Haemost Thromb 2006; 35:133-5. [CrossRef] 